IRA International Journal of Management \& Social Sciences

ISSN 2455-2267; Vol.08, Issue 02 (August 2017)

Pg. no. 213-220

Institute of Research Advances

http://research-advances.org/index.php/RAJMSS

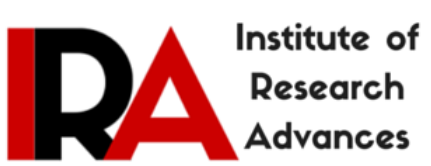

\title{
Customer Loyalty of the Cement Products: The Role of Marketing, Service Quality and Customer Satisfaction
}

\author{
Dachlan Taha ${ }^{1}$, Basri Modding ${ }^{2}$, Sabri Hasan ${ }^{3}$, Hamza Ella ${ }^{4}$ \\ ${ }^{1}$ Doctoral Student in the Faculty of Economics, Muslim University of Indonesia, Indonesia. \\ 2,3,4 Faculty of Economics, Muslim University of Indonesia, Indonesia.
}

Type of Review: Peer Reviewed.

DOI: http://dx.doi.org/10.21013/jmss.v8.n2.p9

\section{How to cite this paper:}

Taha, D., Modding, B., Hasan, S., Ella, H. (2017). Customer Loyalty of the Cement Products: The Role of Marketing, Service Quality and Customer Satisfaction. IRA-International Journal of Management \& Social Sciences (ISSN 2455-2267), 8(2), 213-220. doi:http://dx.doi.org/10.21013/jmss.v8.n2.p9

(C) Institute of Research Advances.

\section{(cc) BY-No}

This work is licensed under a Creative Commons Attribution-Non Commercial 4.0 International License subject to proper citation to the publication source of the work.

Disclaimer: The scholarly papers as reviewed and published by the Institute of Research Advances (IRA) are the views and opinions of their respective authors and are not the views or opinions of the IRA. The IRA disclaims of any harm or loss caused due to the published content to any party.

Institute of Research Advances is an institutional publisher member of Publishers Inter Linking Association Inc. (PILA-CrossRef), USA. The institute is an institutional signatory to the Budapest Open Access Initiative, Hungary advocating the open access of scientific and scholarly knowledge. The Institute is a registered content provider under Open Access Initiative Protocol for Metadata Harvesting (OAI-PMH).

The journal is indexed \& included in WorldCat Discovery Service (USA), CrossRef Metadata Search (USA), WorldCat (USA), OCLC (USA), Open J-Gate (India), EZB (Germany) Scilit (Switzerland), Airiti (China), Bielefeld Academic Search Engine (BASE) of Bielefeld University, Germany, PKP Index of Simon Fraser University, Canada. 


\begin{abstract}
The purpose of this study was to analyze marketing, service quality and its impact on customer satisfaction and customer loyalty, and analyze the influence marketing and service quality on customer loyalty as a mediator customer satisfaction. Research conducted in South Sulawesi province with a sample of 215 local and national developers who use Tonasa cement products. Data from the questionnaires were analyzed using Structural Equation Model using AMOS 18 and Sobel test for mediator effect. The study found that marketing has a negative and no significant effect on customer satisfaction. In general the users complained marketing Tonasa cement applied by the cement Tonasa Company and this is the cause of marketing judged negatively, thus providing insignificant effect on customer satisfaction. Services quality has a positive and insignificant effect on customer loyalty. Service quality has done well, but the demand for service quality shown Tonasa Cement Company contributes insignificant effect on customer loyalty. Marketing has a negative and insignificant effect on customer loyalty as a mediator customer satisfaction. It shows that all the indicator do not provide reinforcement to the marketing variables that cause a negative impact and customer satisfaction is not able to mediate to have a significant effect on customer loyalty.
\end{abstract}

Keywords: Marketing, service quality, customer satisfaction, customer loyalty

\title{
Introduction
}

The development and progress of a region such as a province has always been characterized by the rapid development of infrastructure development such as road construction concrete, high rise buildings (hotels, shopping centers and office buildings), housing and facilities commonly owned by the province. The developments activities cannot be separated from the use of materials one of which is cement with different types of cement brands are available in one province. As in South Sulawesi province there are four dominant species marketed, among others Tonasa, Bosowa, Indocement and Holcim cement. Fourth dominant type of cement is marketed in South Sulawesi with various references in the possession advantage. Tonasa cement company has the advantage of high pressure cement for housing, bridges, multi-storey buildings and concrete; cement for the construction of concrete, stucco, bricks; cement for the construction of multi-storey buildings and coastal areas; passed the ISO standards; and Quality Certified Laboratory (ISO 9001: 2000, ISO 14001: 2004).

Further advantages of Bosowa cement is cement raw material Portland hydraulics of composite cement, marketing only in the region of Central Indonesia, has cement that is adhesive and cohesive as a binder. Besides Bosowa cement has passed SNI for poltland cement type I, and has ISO 9001 and ISO 14001, for building, concrete construction and the environment. Indocement Company in marketing the product having the same advantages with other cement, that is for public used i.e. for houses high-rise buildings, bridges, roads and concrete construction. Indocement product also has a Quality Management System Certification ISO 9001: 2008 and ISO 14001: 2004 to ensure good corporate governance practices.

Holcim cement company with cement product excellence suitable for brick lightweight, easy to apply product with high adhesive power and efficient power usage for mixed specific thinner. The other advantage is reducing the fine of cracks on the walls, so the wall is more perfect. Holcim has a standard ISO 9001, ISO 14001 and OHSAS 18001 accreditation and graduation standards. The cement industry is a strategic industry that developed rapidly in the country. In line with the improvement in economic growth and welfare of the people, the potential demand for cement continues to increase between $8 \%$ between $10 \%$. Huge market potential and levels of increasingly sharp competition demands the precision management of the company to develop marketing concepts, quality of service, customer satisfaction and loyalty (Soetjipto, 2013: 1).

Fourth foregoing become the latest thing as a novelty that needs to be examined from the aspects of the phenomenon, reality, data and gaps associated with it to be observed and observed in connection with the implementation of the top leader played in determining company policies for continues to grow and compete with competitors who engaged in the same field. Facing the competition was certainly a cement company discovered various problems and obstacles in the field of marketing that must be faced and resolved. Problems faced by the cement company in South Sulawesi, particularly Bosowa and Tonasa cement Company and is the final consumer loyalty level (project contractor and property developer) which decreased its marketing trend seen from the purchase and sale of cement products in various development activities. Various considerations are owned by the final 
consumer to determine the attitude in the use of cement products of a company depends on the level of the purchase of the repetitive and do not use cement products of other companies, depending on how often the ultimate consumer reference cement products to consumers other engaged in the effort together and how much positive feedback that is built using cement products company.

Conditions of corporate marketing cement products in South Sulawesi, shows there is a gap between the expectations of a cement company with a fact that shows the level of customer loyalty final consumer, which began to decline to perform faithfulness buy repeatedly Tonasa cement products, the reference level is lacking in informing on others of cement products and the lack of a positive response for the excellence of cement products are marketed. Upon consideration of the final consumer will no longer have to make certain brand cement as a flagship product, because many regular customers who are looking for other cement products such as Tonasa cement, Bosowa, Indocement and Holcim are widely marketed in South Sulawesi. Evidence shows that the level of customer loyalty cement end consumers decreased this can be shown by the trend of the marketing, sale and purchase of Tonasa cement, with three other cement companies as a comparison that Bosowa, Indocement and Holcim as cement sold in South Sulawesi in five years Last show the final consumer customer loyalty tends to decrease according to the level of satisfaction with cement products are marketed. More specifically data showed on contractors and developers who make a purchase cement as follows:

Table 1. Marketing cement in South Sulawesi province (percentage)

\begin{tabular}{|c|c|c|c|c|c|c|}
\hline \multirow{2}{*}{ Years } & \multicolumn{5}{|c|}{ Marketing level (\%) } & Satisfaction \\
\cline { 2 - 5 } & Tonasa & Bosowa & Indocement & Holcim & $\begin{array}{c}\text { Loyalty } \\
(\%)\end{array}$ \\
\hline 2012 & 60.7 & 69.2 & 59.4 & 40.8 & 53.4 & 60.8 \\
\hline 2013 & 72.9 & 75.3 & 62.8 & 45.9 & 55.8 & 59.7 \\
\hline 2014 & 65.7 & 76.5 & 63.5 & 53.2 & 54.5 & 57.3 \\
\hline 2015 & 63.8 & 77.9 & 65.7 & 62.8 & 53.2 & 56.8 \\
\hline 2016 & 62.9 & 78.2 & 64.2 & 64.9 & 52.9 & 55.4 \\
\hline
\end{tabular}

Source: Project Developer Building Association (updated March 3, 2017)

Based on the table above, known level of marketing Tonasa cement within five years of the tendency of decreasing trend of marketing, except the years 2012 and 2013 there was an increase from $60.7 \%$ between $72.9 \%$, then from 2014 until 2016 marketing level decreased from 65.7\% to 62.9\%. Compared with marketing Bosowa cement has increased from $69.2 \%$ in 2012, increased to $78.2 \%$ in 2016. Indocement companies increased from 2012 up to 2015 by $59.4 \%$ between $65.7 \%$, but in 2016 dropped to $64.2 \%$. And the Holcim Company saw an increase from 2012 of $40.8 \%$ to $64.9 \%$ in 2016 . As a result, have an impact on customer satisfaction and loyalty end users decreased. Visible customer satisfaction showed a downward trend from the year 2012 amounted to 53.4\% until 2016 amounted to $52.9 \%$. While customer loyalty shows the percentage decline began in 2011 amounted to $60.8 \%$ till 2015 to $55.4 \%$.

The occurrence of the downward trend in the level of customer satisfaction and loyalty in this case the final consumer, due to the implementation of marketing and service quality is not maximized. This is a phenomenon starting to be seen and observed, so that a key input cement company, especially Tonasa cement in marketing their products. The above phenomenon shows the level of customer loyalty final consumer dropped, not in spite of the fact that some in the field that there is an indication of customer loyalty decreased due to the level of repeat purchases of end consumers decreased, less recommend to final consumers more to continue to make a purchase and no interpretation negative responses are not healthy on cement products are marketed, so there is a tendency for the end consumers are less loyal make purchases cause marketing Tonasa cement decreased.

Understanding that customer loyalty is decreasing, need to be improved by applying the theory of loyalty assumption of Norman (2005: 87) states that loyalty is customer please attitude and always use the product repeatedly and has a positive feedback on the product used. On this basis then the cement company should be able to consider the orientation of customer loyalty to the end consumer, namely the developers of housing and building projects. The next fact is found in general that the final consumer as a customer often complain of cement products bought from Tonasa Cement Company. Complaints and dissatisfaction often do not get the channel or container to listen to the voice of the customer. As a matter of fact end customer also realize that a lack of awareness of the 
company in the management system of complaints and suggestions cause cannot determine the level of customer satisfaction, but it is rarely conduct a survey on customer satisfaction in fact, the company has limited to ghost shopping for the detection sensitivity of the products that customers use. And the management company also rarely makes contact with the customer as the final consumer who needs to get attention form. As a result of the lack of consideration and attention to the final consumer much less satisfied.

Upon consideration of customer dissatisfaction, then policy makers should consider of satisfaction from Kotler (2013: 17) that customer satisfaction can be known through the system of complaints and suggestions, satisfaction surveys, shopping ghost and loyal customers. Understanding the relationship between customer satisfaction and customer loyalty, it has been studied by some previous researchers, among others Marshal (2011) which expressed customers satisfaction with positive and significant impact on customer loyalty, satisfaction negative and significant effect on customer loyalty (Rahim Mosahab, 2010). Mohammad (2015) showed a positive and significant satisfaction on loyalty. Customers' satisfaction is positive and significant impact on customers' loyalty (Muh. Ishaq et al., 2016). Customers satisfaction has a positive and significant on customers loyalty (Hayan and Samaan, 2015; Basir, 2016).

As a result of declining customer satisfaction and loyalty it is necessary to consider aspects of marketing and service quality become problems or obstacles often complained of by the final consumer as a customer Tonasa cement. The phenomenon that is common and is perceived by the end consumer customers cement is marketing problems, in which the Tonasa cement company not able to provide a stock of cement product sufficiently, cement is often depleted in the market, and this has led to increased prices and unstable that could increase as -time in the quarter, rarely promoting innovative, so the brand image caused less impressive, and the uneven distribution of cement among end consumers, thus providing an opportunity to speculation that impact on customer satisfaction and loyalty. On the above phenomenon as the Research gap then should the cement company should be able to notice the importance of the application of marketing by applying the marketing mix by Kotler (2008: 211) that marketing the right product can be made by applying the concept of 4Ps are: product, price, promotion and place. This concept becomes important to be applied to realize the satisfaction and loyalty of customers to purchase products offered Tonasa cement. Understanding the relationship marketing on customer satisfaction and customer loyalty, it has been studied by some previous researchers, among others Marshal (2011) which shows the negative influence of marketing and no significant effect on customer satisfaction and customer loyalty. Marketing is a positive and significant on customer satisfaction and loyalty (Mohammad, 2015). Marketing is positive and significant on customer's loyalty (Suthar B.K., 2014).

The next phenomenon is the quality of services provided by the company to the customer showed Research gap. a low Whereby the cement company in providing services of Tonasa cement Company lack of responsiveness to the demands and the desire to get the respondents in the activities of product purchase. The cement company showed its reliability in providing primary and superior service to customers, lack of caring attitude provide fast and precise. Tonasa cement companies often do not provide physical evidence of the means to make a purchase, so customers usually provide transport to take the cement plant and the company does not provide assurance of service time and guarantee compensation for damage to the product received in place. This is a phenomenon that the qualities of services provided by the Tonasa cement company not realize customer satisfaction and loyalty. Given the importance of the quality of service provided to the customer, then the company should be able to anticipate the realization of outstanding service quality, so that customers have a high loyalty, so it is necessary to apply the theory of dimensions of service quality by Parasuraman (2004: 96) that there are five dimensions to realize the quality of service. These dimensions are responsiveness, reliability, empathy, tangible and assurance. The five dimension of service quality when applied properly will provide increased customer satisfaction and loyalty.

Understanding the relationship of service quality on customer satisfaction and customer loyalty, it has been studied by some previous researchers, among others Marshal (2011), which shows the quality of service is negative and not significant to customer satisfaction and loyalty, Jirawat (2009) with the results of the quality of service positive and significant impact on customer satisfaction and customer loyalty, Rahim (2010) showed a positive and significant service quality on customer satisfaction and loyalty, Niveen (2013) with the results of a weak association between the application service quality to satisfaction. Sabbir (2012) showed a negative service quality and no significant effect on satisfaction and loyalty. Krishna (2010) service quality is a positive and significant on customer's satisfaction. After understanding the above description, the freshness of this study lies in the phenomenon that is 
disclosed, the fact that occurs the data show a declining trend, the opposition between research gap that is not the direction and support of previous studies.

\section{Literature Review and Hypothesis Testing}

There are five variables were observed consisting of two exogenous variables and two endogenous variables. Exogenous variables in this study consisted of marketing and service quality. While the endogenous variables in the form of customer satisfaction among variables and the dependent variable is customer loyalty.

\section{Marketing}

The independent variable marketing refers to marketing mix by Kotler (2008: 211) that the right product marketing can be done by applying the concept of 4Ps are: product, price, promotion and place. This concept becomes important to be applied to realize the customers' satisfaction and customers' loyalty to buy the Products offered.

$\mathrm{H}_{1}$ : $\quad$ Marketing has a positive and significant effect on customer satisfaction

$\mathrm{H}_{2}$ : $\quad$ Marketing has a positive and significant effect on customer loyalty

$\mathrm{H}_{3}$ : $\quad$ Marketing has a positive and significant effect on customer loyalty as a mediated customer satisfaction

\section{Service quality}

The other independent variables of service quality which refers to service quality dimensions of Parasuraman (2004: 96) that there are five dimensions to achieve the service quality. These dimensions are responsiveness, reliability, empathy, tangible and assurance. The five dimension of service quality when applied properly will provide increased customer satisfaction and customer loyalty.

$\mathrm{H}_{4}$ : $\quad$ Service quality is a positive and significant effect on customer satisfaction

$\mathrm{H}_{5}$ : $\quad$ Service quality is a positive and significant effect on customer loyalty

$\mathrm{H}_{6}$ : $\quad$ Service quality is a positive and significant effect on customer loyalty as a mediated customer satisfaction

\section{Customer satisfaction and customer loyalty}

Customer satisfaction as a mediator variable that refers to customers satisfaction by Kotler (2013: 17) that customer satisfaction can be known through the system of complaints and suggestions, satisfaction surveys, activities of ghost shopping and contact persons loyal customers. Customer loyalty as the endogenous variable refers to Norman (2005: 36) that assess customer loyal or disloyal seen from faithfulness to buy back regularly, always recommend reference to the experience to others for services received and show a positive response to the services offered.

$\mathrm{H}_{7}$ : Customers satisfaction has a positive and significant effect on customer loyalty

\section{Methods}

This study was designed to address problems that have been formulated and the goals to be achieved and to test the hypothesis. Observation and interview is used of data collection techniques. There are 215 local and national housing developers as a sample of this research. Data analysis techniques used in explaining the phenomenon in this research is statistical analysis techniques and analysis of Structural Equation Modeling (SEM).

\section{Analysis and Discussion}

Based on the method of determining the value of the model, the first model testing variables are grouped into exogenous and endogenous variables. An exogenous variable is a variable whose value is determined outside the model. While the endogenous variable is a variable whose value is determined by an equation or model relationship is formed. Included in this group of exogenous variables is the measurement of marketing and service quality, while those classified as an endogenous variable is customer satisfaction and loyalty. The model is said to be good when the development of theoretically hypothetical model supported by empirical data. The result of SEM analysis is complete can be seen in the following figure: 


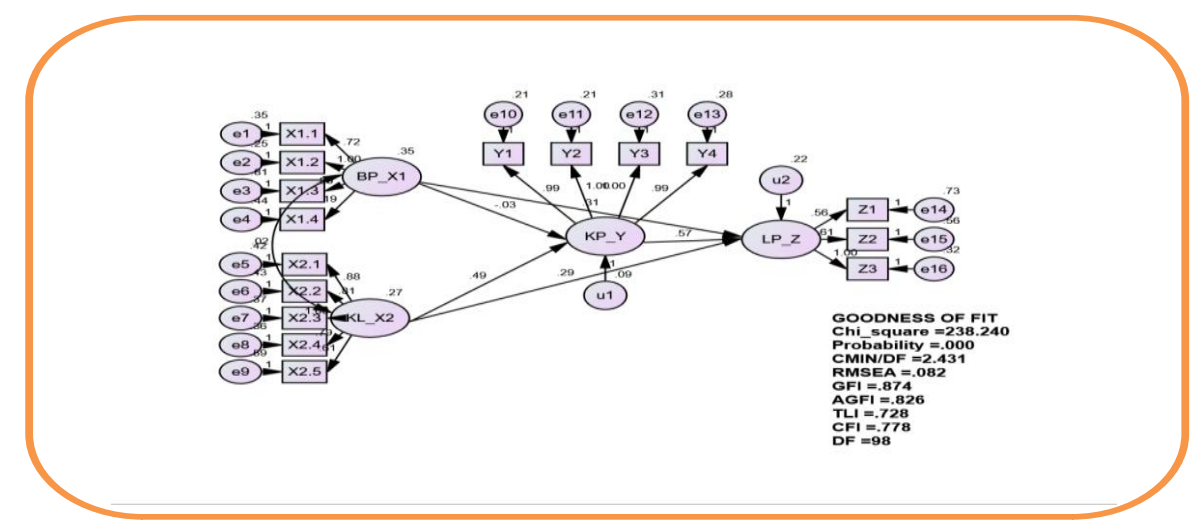

Figure 1. Measurement of the First Model

The evaluation models suggest eight criteria of goodness of fit indices seen the chi-square value is still great and seemingly some of the criteria are not in accordance with the values cutoff were determined so that modifications done by performing the correlation between the model error indicator according to the instructions of the modification indices. The results of the analysis after the final model obtained are as follows:

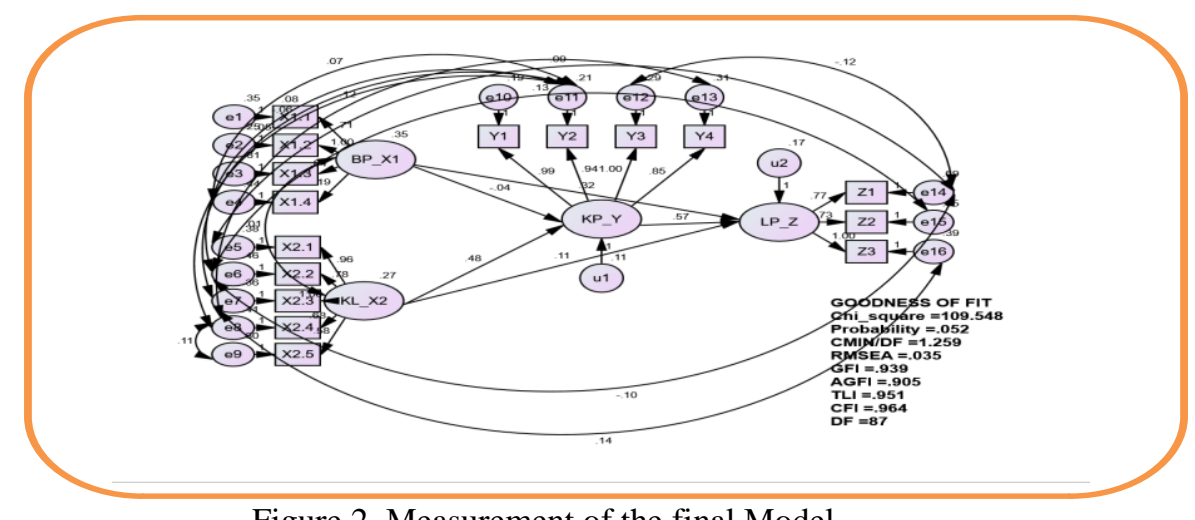

Figure 2. Measurement of the final Model

The results of the test model is presented in Figure 2 above are evaluated based on the goodness of fit indices in Table 2 below with the presented criteria of the model as well as critical values that have compatibility of data.

Table 2. Evaluation criteria of Goodness of Fit Indices Overall Model

\begin{tabular}{|c|c|c|c|c|c|}
\hline $\begin{array}{c}\text { Goodness of } \\
\text { fit index }\end{array}$ & $\begin{array}{c}\text { Cut-off } \\
\text { Value }\end{array}$ & First Model & annotation & Final Model & annotation \\
\hline Chi_square & $\begin{array}{c}\text { Expect } \\
\text { small }\end{array}$ & $\begin{array}{c}238240(0,05: 98= \\
122.1077)\end{array}$ & Marginal & $\begin{array}{c}109548(0,05: 87= \\
109.7733)\end{array}$ & Good \\
\hline Probability & $\geq 0.05$ & 0.000 & Marginal & 0.052 & Good \\
\hline CMIN / DF & $\leq 2.00$ & 2,431 & Marginal & 1,259 & Good \\
\hline RMSEA & $\leq 0.08$ & 0082 & Marginal & 0035 & Good \\
\hline GFI & $\geq 0.90$ & 0874 & Marginal & 0939 & Good \\
\hline AGFI & $\geq 0.90$ & 0826 & Marginal & 0.905 & Good \\
\hline TLI & $\geq 0.94$ & 0728 & Marginal & 0951 & Good \\
\hline CFI & $\geq 0.94$ & 0778 & Marginal & 0964 & Good \\
\hline
\end{tabular}

The results of the evaluation model for early stage shows of the eighth criteria for goodness of fit indices that meet the criteria have not been any cut-off value, so that the necessary modifications to the model according to the instructions of the modification indices. Modification Indices (MI) is a calculation to make changes to the figures, where the figures below indicate substantial minimum value chi-square will go down if the corresponding variable is connected. After the modification of the model, then the final stage of the eight criteria indicate the goodness of fit 
indices have met the criteria or the appropriate cut-off value, so the model is said to have been in accordance with the criteria of goodness of fit indices for analysis.

Based on empirical models proposed in this study can be tested against the hypothesis put forward by testing the path coefficients in structural equation modeling. Table 3 is a hypothesis testing see $p$-value, if the p-value less than 0.05 then the relationship between significant variables. It also describes the direct effect means that there are positive influence directly between variables, the indirect effect means that there are positive influence indirectly between variables, and the total effect is the accumulation of direct influence and indirectly. The test results are presented in the following table:

Table 3. Hypothesis Testing

\begin{tabular}{|c|c|c|c|c|c|c|c|c|}
\hline \multirow{2}{*}{\multicolumn{2}{|c|}{ Exogeneus }} & \multirow{2}{*}{\multicolumn{2}{|c|}{ Endogeneus }} & \multicolumn{5}{|c|}{ Regression Weights } \\
\hline & & & & Direct & Indirect & Total & p-value & annotation \\
\hline \multicolumn{2}{|l|}{ Marketing } & \multicolumn{2}{|c|}{ Customer satisfaction } & $-0,040$ & - & $-0,040$ & 0,515 & $\begin{array}{l}\text { Negative } \\
\text { insignificant }\end{array}$ \\
\hline \multicolumn{2}{|l|}{ Service quality } & \multicolumn{2}{|c|}{ Customer satisfaction } & 0,484 & - & 0,484 & 0,000 & $\begin{array}{c}\text { Positive } \\
\text { significant }\end{array}$ \\
\hline \multicolumn{2}{|l|}{ Marketing } & \multicolumn{2}{|c|}{ Customer loyalty } & 0,316 & - & 0,316 & 0,002 & $\begin{array}{l}\text { Positive } \\
\text { significant }\end{array}$ \\
\hline \multicolumn{2}{|c|}{ Service quality } & \multicolumn{2}{|c|}{ Customer loyalty } & 0,109 & - & 0,109 & 0,476 & $\begin{array}{c}\text { Positive } \\
\text { insignificant }\end{array}$ \\
\hline \multicolumn{2}{|l|}{$\begin{array}{l}\text { Customer } \\
\text { Satisfaction }\end{array}$} & \multicolumn{2}{|c|}{ Customer loyalty } & 0,567 & - & 0,567 & 0,000 & $\begin{array}{c}\text { Positive } \\
\text { significant }\end{array}$ \\
\hline Exogeneus & & liator & & Direct & Indirect & Total & $\mathrm{p}$-value & annotation \\
\hline Marketing & \multicolumn{2}{|c|}{$\begin{array}{c}\text { Customer } \\
\text { Satisfaction }\end{array}$} & Customer loyalty & 0,316 & $-0,023$ & 0,293 & $0 ., 528$ & $\begin{array}{c}\text { Negative } \\
\text { insignificant }\end{array}$ \\
\hline $\begin{array}{l}\text { Service } \\
\text { quality }\end{array}$ & \multicolumn{2}{|c|}{$\begin{array}{l}\text { Customer } \\
\text { Satisfaction }\end{array}$} & Customer loyalty & 0,109 & 0,274 & 0,383 & 0,011 & $\begin{array}{c}\text { Positive } \\
\text { significant }\end{array}$ \\
\hline
\end{tabular}

The overall model shows five effect of direct and indirect two pathways hypothesized, seen three straight path give a positive and significant impact, while the straight path and the negative and insignificant effect, as well as a direct path with the positive and insignificant. For the indirect effect, visible one indirect effect has a negative and insignificant, as well as an indirect pathway positive and significant. The interpretation of Table 3 can be explained as follows:

(1) Marketing has a negative and insignificant effect customer satisfaction with the coefficient value of $-0,040$ and $\mathrm{p}$-value $0,515>0,05$

(2) Service quality has a positive and significant impact on customer satisfaction with the coefficient value of 0,484 and $p$-value of $0,000<0,05$

(3) Marketing has a positive and significant effect on customer loyalty with the coefficient value of 0,316 and p-value of $0,002<0,05$

(4) Service quality has a positive and insignificant effect on customer loyalty with the coefficient value of 0,109 and p-value $0,476>0,05$

(5) Customers' satisfaction has a positive and significant effect on customer loyalty with the coefficient value of 0,567 and $p$-value of $0,000<0,05$

(6) Marketing have a negative and insignificant effect on customer loyalty as a mediated customer satisfaction with the coefficient value of $-0,023$ and $p$-value $0,528>0,05$

(7) Service quality has a positive and significant effect on customer loyalty as a mediated customer satisfaction with the coefficient value of 0,274 and $p$-value of $0,011<0,05$.

Based on the above interpretation, to determine the mediating variables in this case customer satisfaction which is insignificant if it is still capable of as a mediator in the relationship, then tested Sobel test in order to know how much the role of mediating variables are mediating. More details are shown as follows: 


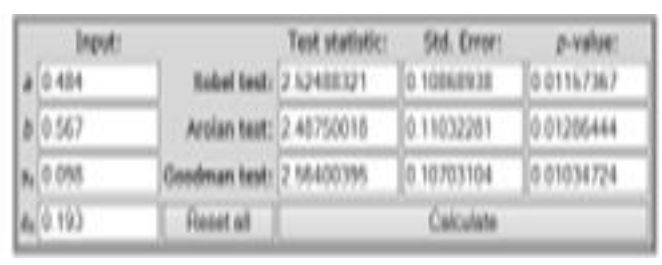

Figure 3. Marketing on customer loyalty as a mediated customers satisfaction

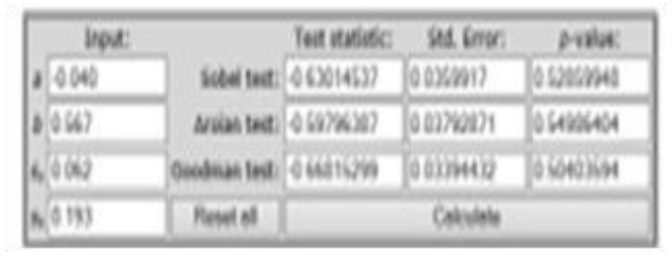

Figure 4. Service quality on customer loyalty as a mediated customers satisfaction

The above calculation results Sobel test scores for 2,525 > 1.98 with a significance level of $0,011>0.05$, shows that customer satisfaction is able to mediate the relationship of service quality on customer loyalty (figure 3 ). The results of the above calculation Sobel test scores of $-0,630<1,98$ significance level of 0,528 $>0,05$, proving bahaw customer satisfaction proved incapable of mediating relationship marketing clout to cement customer loyalty (figure 4).

\section{Conclusion}

Based on the analysis and discussion of the results of research, summarized as follows: 1) marketing has a negative and insignificant effect on customer satisfaction. All indicators provide less variable reinforcement on the marketing variables, which cause no significant effect on customer satisfaction; 2) service quality positive and significant effect on customer satisfaction. It shows all the indicator variables provide a strong influence on the service quality and it also gives a significant impact on customer satisfaction; 3) marketing has a positive and significant effect on customer loyalty. This means that marketing has been applied by the Tonasa cement company and get a response from the customer loyalty level; 4) services quality is a positive and insignificant effect on customer loyalty. The service quality provided by the company to the customer has done well, but the demands of the quality of service that indicated the Tonasa cement company insignificant because of the service quality not as an assessment of the customers loyalty, but judging from the products produced by the company; 5) customer satisfaction is a positive and significant effect on customer loyalty. Customer satisfaction has always been the attentions of the company in an effort to enhance customer loyalty to continue to buy Tonasa cement product; 6) marketing have a negative and insignificant effect on customer loyalty as a mediated customer satisfaction. All indicator variables do not provide reinforcement to the variable marketing and customer satisfaction are not able to mediate; and 7) the service quality is a positive and significant effect on customer loyalty as a mediated customer's satisfaction. It shows that all the indicator variables have provided reinforcement to the variable service quality and customer satisfaction capable of mediating variables to have a significant effect on customer loyalty.

\section{References}

[1] Kotler, Philip and Gary Armstrong. (2010). Principles of Marketing, $6^{\text {th }}$ ed. Englewood Cliffs, NJ: Prentice-Hall International, Inc.

[2] Kotler, Philip dan Keller, KL (2010). Principles of Marketing. $10^{\text {th }}$ ed. Published of Prentice Hall, New Jersey.

[3] Kotler, Philip. (2008a). Marketing Management, Analysis Planning, Implementation and Control. Issue 9. PT. Prenhallindo, Jakarta.

[4] Kotler, Philip. (2008b). Marketing Management and Consumer Behavior. The Millennium Edition.Prentice Hall, Inc. New Jersey.

[5] Kotler, Philip. (2009). Marketing Management. First and second edition. Prenhallindo, Jakarta.

[6] Kotler, Philip. (2010). Marketing Management. The Millennium Edition, Ten Edition, USA: Prentice Hall., Inc.

[7] Kotler, Philip.(2012). Marketing Management:Analysis, Planning, Implementation, and Control, $9^{\text {th }}$ ed. Englewood Cliffs, NJ: Prentice-Hall International, Inc.

[8] MA. Farrel, (2009). Application of Marketing Mix to Increasing of Customer Satisfaction and Loyalty.

[9] Marcel, Davidson, (2003). Service Quality in Concept and Theory. Published by American Press, USA.

[10] Norman, Davis, (1992). Service Management System. Prentice Hall Ohio University Press, USA.

[11] Oemi RS, (1995). Marketing and Service. John Wiley and Sons Published, Ohio University.

[12] Parasuraman, A. Valerie, (2001). Delivering Quality Service. The Free Press, New York.

[13] Stonner, Stephen, (2008). Marketing Competitive. Prentice Hall Cliffs, New Jersey.

[14] Sugiyono, (1992). Quantitative Research Method. Gunung Agung, Jakarta.

[15] Swastha, Basu, (2011). Marketing concept: Attitude and Sales Behavior. Elex Media Komputindo, Jakarta. 